\title{
Mulling over Manganyi's mind: Lessons for rethinking black subjectivity in the decolonial moment
}

The publication of Chabani Manganyi's (2016) intellectual autobiography, Apartheid and the making of a black psychologist, has once more stimulated a critical engagement with his oeuvre. Whilst there are multiple potential readings of this recent work, I am specifically interested in a selective reading of black subjectivity through this text, especially in the context of the decolonial moment that has come to characterise much of our contemporary politics, and in which black subjectivity itself has become a much debated issue.

This current decolonial impulse is by no means new and "has long existed in different ways, opposing what could be called the colonizing turn in Western thought ... the paradigm of discovery and newness that also included the gradual propagation of capitalism, racism, [and] the modern/gender system" (Maldonado-Torres, 2011: 1). As such, it is fundamentally about adopting a skeptical epistemic attitude towards Western modernity and its associated forms of knowledge, power, being and praxis. It is therefore not surprising that decolonial theory currently has significant purchase power in the analyses of postcolonial contexts, because its overarching premise rests in the critique of Western modernity, its terrors and its intractable internal contradictions. Here, a critical scrutiny of the relationship between science, knowledge, context and history, as well as the uncovering and illumination of subordinated knowledges and ways of being in the world, are central to the decolonial project. Manganyi's autobiography provides a valuable literary foil to examine some selective questions pertaining to ways of being and subjecthood in particular, such as memory and subjectivity; race and subjectivity;
Garth Stevens

Department of Psychology

School of Human \&

Community Development

University of the

Witwatersrand

Garth.Stevens@wits.ac.za 
embodiment and subjectivity; and knowledge and subjectivity - not only in our past, but within contemporary South Africa.

Part of the perennial intrigue with Manganyi's oeuvre is perhaps related to the fact that most of his intellectual work has engaged deeply with the relationship between context and subjectivity, but often runs counter to the dominant intellectual stream of the time, and always invokes a consideration of the black experience. Manganyi's intellectual footprint, both inside psychology and outside of it, has ranged from the 1970s through to 2016, with notable contributions on: Being-black-in-the-world; Mashangu's reverie, and other essays; Looking through the keyhole; Political violence and the struggle in South Africa, edited with André du Toit; Psychology and racial difference; Democracy, transition and transformation in South African society; not to mention his biographies on Gerard Sekoto, Es'kia Mphahlele and Dumile Feni. Despite these contributions, for a number of reasons his work has not necessarily garnered the due recognition within mainstream psychology in South Africa, other than in the terrain of critical and community psychology or in the works on psychology's social relevance (see for example, Ratele \& Shefer, 2007; Hayes 2011; Hook, 2014; Long, 2016). His thinking about the black experience in contexts of systemised oppression, his ideas about responses to these forms of domination, his writings on violence and its place in a world that is racialised, the recovery of black thought and practice, and of course, his re-appropriation of psychological knowledge in the service of humanity, are all central intellectual threads in his work, and this text bears all of these hallmarks and more.

The first point worth raising from the text is precisely about the value of the autobiographical, biographical or life-writing format. In the Preface of his book, Manganyi notes that he has tried very hard to come to terms with the first-person nature of memory - he grasps the enormity of the challenge of writing an authentic account from memory. Memory is fragile, and in fact can be downright fickle at times. It is not truth, and so there have been many criticisms directed at the use of memory work that suggests that it can range from an idealisation of the past, to a reactionary reinstatement of that past, to a concealment of the past, to being locked inside a repetition-compulsion of a past (Duncan, Stevens \& Sonn, 2012). Here, the personal storied account is a mnemonic device - telling the story evokes memories, which as they are written or told, can change the very nature of those rememberings in infinite, iterative ways (Stevens, Duncan \& Sonn, 2013). But while storied accounts that utilise memory are perhaps provisional truths, they are as worthy of consideration, as Peterson (2012) points out, as they can also offset the homogenising effects of grand narratives of history and subjectivity (Sonn et al, 2013). They of course also have an aspect of liminality to them. While the past is being recovered to some degree, it is in the context of narrational production that new meanings are attributed to this past potentially, and so they speak about the relationship 
between the past and the present (Stevens et al, 2013). The subject is thus not fixed, but in a state of potential flux in relation to him/herself, in relation to the context, and in relation to the interlocutors who apprehend the story.

What Manganyi does is to illuminate the relationship between memory and subjectivity, and the ways in which memory can be mobilised in the service of positively defining and redefining personhood, as well as the reasons for these variegated subject positions at specific historical moments. Of course, we are also compelled to then ask critical questions about the narrative of ascendancy that threads the book - an account of adversity, defeating that adversity, and culminating with integrity in its resolution. Here, memory is central to a project of crafting a very particular black subject in post-apartheid South Africa, and may reveal interesting possibilities, impossibilities and injunctions about being black in contemporary South Africa (i.e. the tolerable versus intolerable black subject in neo-liberal South Africa today, where there is a recognition of the past, but simultaneously an injunction to not have this past generate a paralysis to progress and stability). White subjects are in many instances expected to be mindful of their historical complicity, to reveal some degree of shame, but not promiscuously so, and frequently have to be reflective about the extent to which they can exercise voice publicly (Straker, 2013). Black subjects however, are often expected to articulate their historical adversity, but also to reveal a degree of mastery over this, and to perform a new awareness and vigour through their subjecthood and citizenry (Sullivan \& Stevens, 2013). But of course, the relative absence of an account of the intolerable subject who does not neatly adhere to the narrative of ascendancy is as important a line of inquiry - one that is perhaps less frequently articulated in Manganyi's account of his intellectual life.

The second related point from the book is the use of these personalised accounts to articulate that the black subject is never simply one-dimensional - the black subject meets the world on contradictory terms, but has the capacity for agency, resistance, reappropriation and reconstitution. Manganyi describes these processes through his contact with both whites and blacks, revealing the often ambivalent and contradictory nature of these relationships and contexts. One reading of the text may suggest that there is a great deal of emphasis by Manganyi on his relationships with white colleagues and mentors throughout significant periods in his life, perhaps indicating an internalised deference towards whiteness. But Manganyi also offers a more complex account. Whilst recognising the pernicious effects of mission schooling and the aberrations of Bantu Education, he nevertheless considers these as having had a profound impact on the value that he attaches to education - pointing to the possibilities of exploiting these spaces with their internal contradictions as well. His time as a black clinician recapitulates previous experiences of marginalisation and exclusion, but it is also a site for mastery and the development of specialised psychological skills and acumen. His short period in the USA opens up the

PINS [Psychology in Society] 52 • 2016|92 
entire terrain on both the homogeneity and heterogeneity of blackness as well. Not only is he differentiated from African-Americans in the context of affirmative action when he is not successful for a job application, but he also experiences his own black rage in relation to living in apartheid South Africa. Here, Said's (2000) conception of the transgressive possibilities in an exilic consciousness becomes useful - the consciousness of the exile in which one belongs to and in multiple contexts, but is never fully immersed in any of them. Whilst this is potentially a form of being unrooted, it is also a form of dislocation from context that allows one to be both inside and outside simultaneously - prompting distance and a degree of transgression that is not always possible within one's natural habitat - allowing for an engagement with his own rage in relation to apartheid South Africa. His period at the University of Transkei is also characterised by an initial optimism at being able to offer tertiary level education to black South Africans, but is also marked by increasing draconianism within the Bantustan system, eventually leading to him experiencing it as an untenable intellectual environment.

Clearly, Manganyi is implicitly articulating the view that where power is operant, there is also always the possibility for resistance, but also that black subjectivity (and by extension, white subjectivity) is systemically complex and is further relationally complicated by our experiences of the Other as both positive and negative in interpersonal contexts. This systemic and relational question between blacks and whites remains with us profoundly today, both personally and politically, as we attempt to define how to engage from various standpoints and histories - privilege, marginalisation, multi-culturalism, nonracialism, anti-racism, Africanism, and so forth. In the present juncture when there are legitimate calls for the re-examination of black and white subjectivity, there are also increased racialised polarisations and a return to narrow racialised essentialisms. Whilst appreciating the political import of strategic essentialism at specific historical moments (see Biko, 1979, on the debate around the relationship between the Black Consciousness Movement and white liberals), bell hooks (1995) cautions against narrowly defined, monolithic identity politics that tend to invisibilise the complex, intersectional and diverse nature of subjectivities. To this end, Manganyi's autobiography will be one important resource to return to. New questions about the rights attributed to various social subjects; revisiting the intersectional nature of raced, classed and gendered subjectivities; interrogating whether the focus of our attention should be on black and white subjects as opposed to blackness and whiteness; and how we create new global solidarities based on more complex subjectivities; will all be critical for us in this decolonial moment - an interregnum in which the new is yet to be born and the old is not yet dead (Gramsci, 1971).

The third point I would like to retrieve from Manganyi's book is the relationship between embodiment and subjectivity. In several relatively minor references within the text, he 
refers to his clinical work in a state hospital servicing black patients, where he encounters black female patients with symptoms of hysteria, conversion disorders or functional neurological symptom disorders. This was of significance in apartheid South Africa, as it provided an exemplar (however seemingly dysfunctional) of how embodied subjectivity emerged even in the face of the infra-humanisation and psychic sequestration of blacks. Fanon (1961) similarly suggested that within coloniality (and by extension in postcolonial contexts), black subjects are reduced to objects partly through collapsing historical racial schemas into bodily schemas, and ultimately into racial epidermal schemas - a process in which there is the bifurcation of the soma and psyche, and the sum total of the black subject is reduced to skin colour. Under these conditions, the psychic worlds of black subjects are declared absent and obliterated for all intents and purposes. Deploying the primacy of the black body's "pain", either consciously, neurotically or psychotically as a response to the bifurcation of the black soma and psyche may be understood as an organic response to reconstitute and reclaim these enigmatic psychic components (see also Butler, 1993; and Merleau-Ponty, 2013, for accounts of the body as a representational surface and a site for the materialized expression of subjectivity and personhood). Manganyi's instructive insights into the corporeal subject may offer up alternative understandings of embodied enactments in forms of social protest and violence in contemporary South Africa. Here, the body can be seen as a canvass, as an instrument of power, as a communicative tool, as a mode of reinstating citizenship, and of course, as means of reconstituting obliterated psychic space - where embodied enactments are not simply ephemeral moments of irrationality, primordiality or psychically regressed states of being in the world, but are the materialized manifestations of subjectivity that require analyses in and of themselves.

The final point that I would like to recover from the text relates to knowledge and its constitutive, reproductive and contestatory role in subject formation. Knowledge helps us to craft understandings of ourselves, others and the world, and in so doing, are central to processes of personhood and subjecthood, shifting in and out of hegemonic and subordinated positions, making it a key feature of what kind of subjects can be possible at any given point in history. Here of course, I am alluding to matters of epistemic contestation, disobedience, rupture and reconstruction or cognitive justice, as writers such as Anibal Quijano (2000) have referred to. Manganyi's journey through psychology as a discipline is perhaps a mirror of the challenges faced by many disciplines that are internally contested by subordinated epistemes, today in particular, but also more generally across various temporal moments. His engagement with the conservative forms of psychological science of the early $20^{\text {th }}$ century; his own intellectual tussles with hegemonic epistemes in trying to deliberately uncover and recover black subjectivity and the experiences of the "vandalised minds" of black South Africans under apartheid; his analyses of state-sanctioned violence and counter-violence; and his tactical use of mainstream psychological knowledge in the 
defence and support of victims of apartheid; are all exemplars of epistemic contestation and reconstruction. The point to make here is that disciplines are not static - they are fluid and knowledge is temporally and contextually mobile, allowing us to think about the limits of its possibilities and the insertion of new kinds of knowledges in the recovery of intellectual potency as subjects. In the past several years, there have been many debates about the decolonisation of universities and their curricula, of course involving the central features of challenging forms of knowledge, power and ways of being. Manganyi's intellectual threads, that have spanned more than four decades, are an illustrative exemplar of the very ideas of epistemic disobedience, contestation, rupture and reconstruction. In this context, we should perhaps avoid the pitfalls of thinking that the fractured and incomplete archive of Western thought can and should simply be replaced by another archive of sorts. Whilst a new archive must of course be robustly encouraged and pursued, and we should be engaged with an expanded archive and new forms of subjecthood, there are also spaces within existing epistemes that are sites for contestation, reinterpretation and reconstruction.

Manganyi's memoir aptly illustrates to us that as we think about bending the curve of the moral universe towards the ideals of emancipation, egalitarianism and collective well-being, that we will have to avoid recoiling into nihilism, fatalism, and narrow essentialisms, and seriously begin crafting new forms of critical humanism based on complex subjectivities.

\section{References}

Biko, S (1979) I write what I like. London/Nairobi: Heinemann Educational Books (African Writers Series).

Butler, J (1993) Bodies that matter: On the discursive limits of "sex". New York: Routledge.

Duncan, N, Stevens, G \& Sonn, C (2012) Of narratives and nostalgia. Peace \& Conflict. Journal of Peace Psychology, 18(3), 205-213.

Fanon, F (2005) The wretched of the earth. New York: Grove Press (French-1961).

Gramsci, A (1971) Selections from the prison notebooks. New York: International Publishers Company (Italian-1948).

Hayes, G (2011) (Re-)introducing N Chabani Manganyi. PINS (Psychology in society), 41, 1-6.

Hook, D (2014) Antagonism, social critique and the "violent reverie". PINS (Psychology in society), 46, 21-34. 
hooks, b (1995) Killing rage. New York: Henry Holt.

Long, W (2016) A history of "relevance" in psychology. London: Palgrave Macmillan.

Maldonado-Torres, $\mathrm{N}$ (2011) Thinking through the decolonial turn: Post-continental interventions in theory, philosophy, and critique - An introduction. Transmodernity, 1(2), 1-15.

Manganyi, N C (2016). Apartheid and the making of a black psychologist.

Johannesburg: Wits University Press.

Merleau-Ponty, M (2013) Phenomenology of perception. London: Routledge (French-1945).

Peterson, B (2012) Dignity, memory, truth and the future under siege: Reconciliation and nation building in post-apartheid South Africa, in Shapiro, M \& Opondo, S (eds) The new violent cartography (pp 214-233). New York: Routledge.

Quijano, A (2000) Coloniality of power, Eurocentrism, and Latin America. Nepantla: Views from South, 1(3), 533-580.

Ratele, K \& Shefer, T (2007) Bodies and apartheid, in Ratele, K \& Duncan, N (eds) Social psychology: Identities and relationships (pp 87-106). Lansdowne: UCT Press.

Said, E W (2000) Reflections on exile and other essays. Cambridge, MA: Harvard University Press.

Sonn, C C, Stevens, G \& Duncan, N (2013) Decolonisation, critical methodologies, and why stories matter, in Stevens, G, Duncan, N \& Hook, D (eds) Race, memory and the apartheid archive: Towards a transformative psychosocial praxis ( $p p$ 295-314). London/Johannesburg: Palgrave Macmillan/Wits University Press.

Sullivan, L G \& Stevens, G (2013) Gendered subjectivities and relational references in black women's narratives of apartheid racism, in Stevens, G, Duncan, N \& Hook, D (eds) Race, memory and the apartheid archive: Towards a transformative psychosocial praxis (pp 208-227). London/Johannesburg: Palgrave Macmillan/Wits University Press.

Stevens, G, Duncan, N \& Sonn, C C (2013) Memory, narrative and voice as liberatory praxis in the apartheid archive, in Stevens, G, Duncan, N \& Hook, D (eds) Race, memory and the apartheid archive: Towards a transformative psychosocial praxis ( $p p$ 2544). London/Johannesburg: Palgrave Macmillan/Wits University Press.

Straker, G (2013) Unsettling whiteness, in Stevens, G, Duncan, N \& Hook, D (eds) Race, memory and the apartheid archive: Towards a transformative psychosocial praxis (pp 91-108). London/Johannesburg: Palgrave Macmillan/Wits University Press. 